\title{
PERFORMANCE OF GINGER GRASS (Lippia alba) FOR TRAITS RELATED TO THE PRODUCTION OF ESSENTIAL OIL
}

\author{
Paula Yuri Yamamoto ${ }^{1 *}$; Carlos Augusto Colombo ${ }^{1}$; Joaquim Adelino Azevedo Filho²; André \\ Luiz Lourenção ${ }^{3}$; Márcia Ortiz Mayo Marques'; Guilherme Domingues da Silva Morais; \\ Alisson Fernando Chiorato ${ }^{4}$; Antônio Lúcio Mello Martins ${ }^{5}$; Walter José Siqueira ${ }^{1}$ \\ IAC - Centro de Pesquisa e Desenvolvimento de Recursos Genéticos Vegetais, C.P. 28 - 13020-902 - Campinas, \\ SP - Brasil. \\ 2APTA - Pólo Regional de Desenvolvimento Tecnológico dos Agronegócios do Leste Paulista, C.P. 01 - \\ 13910-000 - Monte Alegre do Sul, SP - Brasil. \\ ${ }^{3}$ IAC - Centro de Pesquisa e Desenvolvimento de Fitossanidade, C.P. 28 - 13020-902 - Campinas, SP - Brasil. \\ ${ }^{4}$ IAC - Centro de Análise e Pesquisa Tecnológica do Agronegócio de Grãos e Fibras, C.P. 28 - 13020-902 \\ Campinas, SP - Brasil. \\ 'APTA - Pólo Regional de Desenvolvimento Tecnológico dos Agronegócios do Centro-Norte, C.P. 24 - \\ 15830-000 - Pindorama, SP - Brasil. \\ *Corresponding author <paulayamamoto@gmail.com>
}

\begin{abstract}
Lippia alba (Verbenaceae) is a shrub whose essential oil has important biological, pharmacological, and aromatizing properties. To reach the sustained cultivation of new species with economic potential, the present study aimed to evaluate $L$. alba performance for fresh leaf matter (FM), leaf dry matter (DM), virus symptoms (VS - Cucumber mosaic virus, CMV), oil yield (OY), and oil chemical composition (OC), and to evaluate DM stability and adaptability. Ten genotypes of four chemical groups (chemotypes) were evaluated in six experiments designed as randomized blocks with two plants per plot, over the whole State of São Paulo, Brazil. A $2.0 \times 0.4 \times 1.6 \mathrm{~m}$ spacing was used in Monte Alegre do Sul and Pindorama, while a $1.0 \times 0.4 \times 0.6 \mathrm{~m}$ spacing was used in Campinas, where four experiments were established under different irrigation and fertilization conditions. The genotype effect was significant $(p<0.05)$ for all traits evaluated, with high leaf productivity of IAC-16 (citral chemotype), best OY means in the linalool and limonene/carvone chemotypes, and susceptibility of the latter chemotype to CMV. The genotype performance oscillations in the six environments were significant for FM and DM, and despite their significance for phytochemical traits (OY and OC), they were of low magnitude. No qualitative variation was detected for OC. The IAC-2 (linalool) and IAC-13 (limonene/carvone) genotypes showed high stability and wide adaptability, and are recommended to establish initial cultivations of this species. This research also indicated genetic sources to start Lippia alba genetic breeding programs.

Key words: $\mathrm{G} \times \mathrm{E}$ interaction, phenotypic stability, sustainable agriculture, genetic breeding, clonal selection

\section{DESEMPENHO DA ERVA-CIDREIRA (Lippia alba) PARA CARACTERÍSTICAS RELACIONADAS À PRODUÇÃODE ÓLEOSESSENCIAIS}

RESUMO: A Lippia alba (Verbenaceae) é um arbusto produtor de óleo essencial com importantes atividades biológicas, farmacológicas e aromatizantes. Visando o cultivo sustentado de uma nova espécie com potencial econômico, os objetivos deste trabalho foram avaliar o desempenho da $L$. alba para massa de folha fresca (MF), massa de folha seca (MS), sintomas de vírus (SV - Cucumber mosaic virus, CMV), rendimento de óleo essencial (RE) e composição química do óleo (CQ), e avaliar a estabilidade e adaptabilidade fenotípica para o caráter MS. Dez genótipos pertencentes a quatro grupos químicos foram testados em seis experimentos instalados no estado de São Paulo, Brasil, com delineamento em blocos ao acaso e duas plantas por parcela. Em Monte Alegre do Sul e Pindorama, foi utilizado espaçamento de $2,0 \times 0,4 \times 1,6 \mathrm{~m}$ e em Campinas, foram instalados quatro experimentos $1,0 \times$ $0,4 \times 0,6 \mathrm{~m}$ sob condições distintas de adubação e irrigação. O efeito de genótipo foi significativo para todas as características avaliadas, revelando elevada produtividade de folhas do IAC-16 (citral), RE 
superior dos quimiotipos linalol e limoneno/carvona e susceptibilidade deste último ao CMV. As oscilações no desempenho dos genótipos nos diferentes experimentos foram de baixa magnitude para os caracteres fitoquímicos (RE e CQ) e nenhuma variação qualitativa foi observada para CQ. Os genótipos IAC-2 (linalol) e IAC-13 (limoneno/carvona) apresentaram-se estáveis para MS e com ampla adaptabilidade, e são recomendados para o início do cultivo da espécie. A presente pesquisa fornece subsídios também para o início de programas de melhoramento genético em L. alba.

Palavras-chave: interação $\mathrm{G} \times \mathrm{A}$, estabilidade fenotípica, agricultura sustentável, melhoramento genético, seleção clonal

\section{INTRODUCTION}

Lippia alba is a bush of the Verbenaceae family frequently used in popular medicine (Ming, 1994). The pharmacological activities (antispasmodic, soothing, and stomach disorders) of its essential oils have triggered the interest of researchers in establishing their effects which resulted in the detection of other important properties, including the aromatic (Frighetto \& Oliveira, 1998) and biological ones (Cáceres et al., 1991; Abad et al., 1997; Alea et al., 1997; Brasileiro et al., 2006). Currently L. alba is a promising plant for the pharmaceutical, aromatic, and perfume industries and may also be indicated for agricultural-chemical industries, due to its proven fungitoxic, insecticidal, and repellent properties (Dubey et al., 1983; Dwivedi \& Kishore, 1990; Kishore \& Mishra, 1991; Rao et al., 2000; Schwan-Estrada et al., 2000; Ibrahim et al., 2001). In addition, $L$. alba can be easily cultivated and has great agronomic potential, with rapid and aggressive development, clonal propagation via cuttings, and rusticity.

The essential oils are produced mainly by the leaves and are formed from the secondary plant metabolism. The usual compounds in this species include mono and sesquiterpenes (Gomes et al., 1993). Both oil composition and plant yield, including biomass, are directly influenced by environmental factors (Vaz et al., 2006), thus representing a challenge to breeders to establish productive and stable genotypes and to keep the chemical uniformity required by the industry. Furthermore, it is necessary to promote self-sustaining products of national interest and conserve the immense Brazilian biodiversity, since it is a native species. The objectives of this work were to evaluate the performance of Lippia alba genotypes for leaf production, virus infection, oil yield, and oil chemical composition under different environmental conditions, analizing genotype $(\mathrm{G})$, environment $(\mathrm{E})$, and $\mathrm{G} \times \mathrm{E}$ interaction effects, as well as to evaluate the plant's phenotypic stability and adaptability for leaf production.

\section{MATERIALAND METHODS}

Ten Lippia alba genotypes of four chemical composition (chemotypes) were selected for the study:
IAC-1 to IAC-4 (linalool), IAC-9 to IAC-11 (myrcene/ camphor), IAC-13 and IAC-14 (limonene/carvone), and IAC-16 (citral). Plants were selected based on differences in plant morphology, oil yield, and the relative proportions of substances in the oil.

Six experiments were carried out in three regions of the State of São Paulo (SP), Brazil, in a randomized block design, with four replicates and two plants (clones) per plot. Four experiments were installed in Campinas ( $22^{\circ} 31^{\prime} \mathrm{S}, 47^{\circ} 02^{\prime} \mathrm{W}, 680 \mathrm{~m}$ ), representing four environments (E1 - with both fertilization and irrigation; E2 - with fertilization but no irrigation; E3 - no fertilization but with irrigation; E4 - no fertilization nor irrigation). As to fertilization, two sidedressing applications of the 04-14-08 $\left(\mathrm{N}, \mathrm{P}_{2} \mathrm{O}_{5}\right.$, $\mathrm{K}_{2} \mathrm{O}$ ) fertilizer were made, and a drip irrigation system was used. A row spacing of $1.0 \mathrm{~m}$ was adopted in these four experiments (environments), with $0.4 \mathrm{~m}$ between clones and $0.6 \mathrm{~m}$ between plots. The other two experiments were carried out in Monte Alegre do Sul (22 $24^{\prime}$ S, $\left.46^{\circ} 24^{\prime} \mathrm{W}, 760 \mathrm{~m}\right)$ (E5) and Pindorama $\left(21^{\circ} 06^{\prime} \mathrm{S}, 48^{\circ} 32^{\prime} \mathrm{W}, 534 \mathrm{~m}\right)$ (E6), with a row spacing of $2 \mathrm{~m}, 0.4 \mathrm{~m}$ between clones, and $1.6 \mathrm{~m}$ between plots, under a sprinkler irrigation system.

Plants in the plot were pruned at the base and the leaves were excised and placed in paper bags. Fresh leaf matter (FM) was obtained shortly after harvesting, while leaf dry matter (DM) was obtained after drying for 30 days at room temperature, until constant weight was achieved.

Essential oil was extracted from $40 \mathrm{~g}$ of leaves dried by hydrodistillation in a Clevenger apparatus for 90 min. Oil yield (OY) was calculated by the formula OY $(\%)=$ oil mass $(\mathrm{g}) \times 100 /$ leaf matter $(\mathrm{g})$. Oil chemical composition (OC) was determined in a gas chromatographer attached to a mass spectrometer. The components were identified by comparative analysis of the substance mass spectrum against the CG-EM system (Nist 62.lib) databank and data from the literature by McLafferty \& Stauffer (1989), using the Adams (1995) retention index. Kovats retention indexes for the substances were all obtained by co-injection of the essential oil with a standard mixture of n-alkanes (C9 C40), applying the Dool \& Kratz (1963) equation. The following routine was used: $50^{\circ} \mathrm{C}, 5 \mathrm{~min} ; 50-190^{\circ} \mathrm{C}$, $5^{\circ} \mathrm{C} / \mathrm{min} ; 190-220^{\circ} \mathrm{C}, 10^{\circ} \mathrm{C} / \mathrm{min}$. 
Cucumber mosaic virus (CMV) symptoms were evaluated based on a score scale from 1 to 5 , as follows: plants without any symptoms; plants with a few leaf mosaic symptoms; leaf mosaic and initial leaf distortion symptoms; leaf mosaic, reduction and distortion in almost the entire plant; and plants with severe leaf mosaic symptoms, reduction and deformation, and dwarfism.

The magnitude of genotypic and environmental effects was determined for the five traits (FM, DM, $\mathrm{OY}, \mathrm{OC}$, and VS) and the $\mathrm{G} \times \mathrm{E}$ interaction was analyzed for FM, DM, OY, and VS. Simple and joint variance analyses and Tukey's test at $p<0.05$ were calculated using the SANEST statistical program (Machado \& Zonta, 1991). For the F-test, single factors were tested by the $\mathrm{G} \times \mathrm{E}$ interaction which, in turn, was tested by the mean squared residues, in a fixed model for blocks and genotypes, and a random model for environments. The mathematical model used for the joint variance analysis was: $\mathrm{Y}_{\mathrm{ijk}}=\mu+\mathrm{G}_{\mathrm{i}}+\mathrm{E}_{\mathrm{j}}+$ $\mathrm{GE}_{\mathrm{ij}}+\mathrm{B} / \mathrm{E}_{\mathrm{jk}}+\varepsilon_{\mathrm{ij}, \mathrm{j}}$, where: $\mu$ is the general mean; $\mathrm{G}_{\mathrm{i}}$ is the effect of the $i^{\text {th }}$ genotype; $E_{j}$ is the effect of the $j^{\text {th }}$ environment; $\mathrm{GE}_{\mathrm{ij}}$ is the interaction effect between the $i^{\text {th }}$ genotype and the $j^{\text {th }}$ environment; $B / E_{j k}$ is the effect of the $\mathrm{k}^{\text {th }}$ block in the $\mathrm{j}^{\text {th }}$ environment, and; $\varepsilon_{\mathrm{ijk}}$ is the random error.

The statistical data entry for DM and FM considered the total values for the plots (two clones); VS was evaluated for both clones separately and the analysis was based on plot means; for the phytochemical traits (OY and OC), leaves of both clones were sampled. For OC, the chemical substances (only those present above $5 \%$ in the oil) were analyzed separately among the Lippia alba genotypes of the same chemotype.

A phenotypic stability and adaptability analysis was conducted for leaf dry matter via the Eberhart \& Russel (1966) method, using the Genes software (Cruz, 2001). This is a monosegmented model based on linear regression analysis for a small number of environments, applied when the interaction is found to be significant in the variance analysis. The material was considered ideal when it has adaptability $\left(\beta_{1}=1\right)$ in both favorable and unfavorable environments and when it has high phenotypic stability with no significant regression deviation $\left(\sigma_{\mathrm{di}}^{2}=0\right)$, which means high predictability. This analysis is calculated based on the model $Y_{i j}=\beta_{0 i}+\beta_{1 i} 1_{j}+\delta_{i j}$ $+\bar{\varepsilon}_{\mathrm{i}}$, where: $\mathrm{Y}_{\mathrm{ij}}$ is the i genotype mean in the $\mathrm{j}$ environment; $\beta_{0 \mathrm{i}}$ is the general mean of the $i$ genotype; $\beta_{1 \mathrm{i}}$ is the linear regression coefficient that measures the response of the $i^{\text {th }}$ genotype to environmental variation; 1 is the coded environmental index $\left(\sum=0\right) ; \delta_{\mathrm{ij}}$ is regression deviation, and; $\bar{\varepsilon}_{\mathrm{i}}$ is the mean experimental error.

\section{RESULTS AND DISCUSSION}

There were differences $(p<0.05)$ for environments $(\mathrm{E})$, genotypes $(\mathrm{G})$, and for the $\mathrm{G} \times \mathrm{E}$ interaction for the fresh leaf matter (Table 1). In the joint assessment of genotypes, the IAC-16 (citral chemotype) had a distinct mean, with $570 \mathrm{~g}$ in the plot. The higher productive potential of IAC-16 in most environments indicates its potential use as a parental element in crosses with other chemotypes of industrial

Table 1 - Fresh leaf matter means (two clones) for ten Lippia alba genotypes in six environments, with genotype (G), environment $(\mathrm{E})$ and $\mathrm{G} \times \mathrm{E}$ interaction effects detected by ANOVA and Tukey's test $(p<0.05)$.

\begin{tabular}{|c|c|c|c|c|c|c|c|}
\hline \multirow{2}{*}{ Genotypes* } & \multicolumn{6}{|c|}{ Environments* } & \multirow{2}{*}{ Means } \\
\hline & E1 & $\mathrm{E} 2$ & E3 & E4 & E5 & E6 & \\
\hline IAC- 1 & $280.3 \mathrm{ABa}$ & $308.7 \mathrm{BCa}$ & $210.4 \mathrm{Ba}$ & $326.1 \mathrm{Ba}$ & $270.6 \mathrm{Aa}$ & $442.1 \mathrm{Aa}$ & $302.5 \mathrm{~B}$ \\
\hline IAC-2 & $319.7 \mathrm{ABa}$ & $355.4 \mathrm{ABa}$ & $214.5 \mathrm{Ba}$ & $376.1 \mathrm{Ba}$ & $247.9 \mathrm{Aa}$ & $458.1 \mathrm{Aa}$ & $323.5 \mathrm{~B}$ \\
\hline IAC-3 & $225.6 \mathrm{Ba}$ & $275.9 \mathrm{BCa}$ & $295.9 \mathrm{ABa}$ & $300.8 \mathrm{Ba}$ & $210.6 \mathrm{Aa}$ & 409.0 Аа & $282.8 \mathrm{~B}$ \\
\hline IAC- 4 & $276.7 \mathrm{ABa}$ & $337.1 \mathrm{ABa}$ & $222.0 \mathrm{Ba}$ & $285.4 \mathrm{Ba}$ & $317.6 \mathrm{Aa}$ & $343.9 \mathrm{Aa}$ & $295.6 \mathrm{~B}$ \\
\hline IAC-9 & 275.7 ABbc & $109.3 \mathrm{Cc}$ & $319.5 \mathrm{ABab}$ & $175.8 \mathrm{Bbc}$ & 309.2 Aab & $576.6 \mathrm{Aa}$ & $276.6 \mathrm{~B}$ \\
\hline IAC- 10 & $220.8 \mathrm{Bb}$ & $289.8 \mathrm{BCab}$ & $270.4 \mathrm{ABab}$ & $342.0 \mathrm{Bab}$ & 453.5 Aab & $547.3 \mathrm{Aa}$ & $345.4 \mathrm{~B}$ \\
\hline IAC- 11 & $199.9 \mathrm{Bb}$ & $168.7 \mathrm{BCb}$ & $314.0 \mathrm{ABb}$ & $386.9 \mathrm{Bab}$ & $245.5 \mathrm{Ab}$ & $638.6 \mathrm{Aa}$ & $308.9 \mathrm{~B}$ \\
\hline IAC- 13 & $290.8 \mathrm{ABb}$ & $318.1 \mathrm{BCb}$ & $254.0 \mathrm{Bb}$ & $267.5 \mathrm{Bbc}$ & $341.1 \mathrm{Ab}$ & $659.7 \mathrm{Aa}$ & $344.3 \mathrm{~B}$ \\
\hline IAC- 14 & $151.5 \mathrm{Bb}$ & $152.6 \mathrm{BCb}$ & $217.7 \mathrm{Bb}$ & 202.0 Bbc & $190.1 \mathrm{Ab}$ & $665.7 \mathrm{Aa}$ & $241.4 \mathrm{~B}$ \\
\hline IAC- 16 & $547.7 \mathrm{Abc}$ & $681.0 \mathrm{ABab}$ & 575.7 Aabc & $943.6 \mathrm{Aa}$ & $328.5 \mathrm{Ac}$ & 435.6 Abc & $569.7 \mathrm{~A}$ \\
\hline Means & $271.1 \mathrm{~b}$ & $282.8 \mathrm{~b}$ & $282.2 \mathrm{~b}$ & $340.0 \mathrm{~b}$ & $287.2 \mathrm{~b}$ & $511.8 \mathrm{a}$ & 324.5 \\
\hline
\end{tabular}

$\mathrm{CV}=19.1 \% \quad \mathrm{G} \times \mathrm{E}$ interaction*

Means followed by the same letter are not different $(p<0.05)$ between genotypes (capital letters) and environments (lower case letters). *Significant at $p<0.05$. E1: with both fertilization and irrigation (Campinas); E2: with fertilization but no irrigation (Campinas); E3: no fertilization but with irrigation (Campinas); E4: no fertilization or irrigation (Campinas); E5: Monte Alegre do Sul; E6: Pindorama. 
interest to increase leaf production. Its performance in the distinct environments was different from the other genotype profiles. The best means for IAC-16 were detected in Campinas (E1, E2, E3, and E4), especially for E4 (no fertilization or irrigation), demonstrating the rusticity of the most productive material here detected. As to the other nine genotypes, the best means were observed in Pindorama (E6), although no variation was detected in six experiments for the linalool chemotype, as well as among genotypes.

The high leaf production in Pindorama (512 g) can be explained by the hotter climate of that region as compared to Campinas and Monte Alegre do Sul. In addition to climate, several factors contributed to establish distinct environmental conditions and induce plant performances, such as soil, irrigation system, fertilization etc. Such lack of uniformity in plant response when submitted to different cropping conditions is well known. Ming (1994) tested organic fertilizer treatments in L. alba and managed to increase plant biomass but, at the same time, there was a decrease in essential oil contents. Stefanini et al. (2002) did not report differences in leaf production when different combinations of plant regulators were used, but variations were significant in relation to harvest season. For other species, leaf dry matter changed with the use of hormones, as in Cymbopogon spp. (Ellabban, 1978; Bhatnagar \& Asnari, 1988) and Mentha piperita (ElKeltawi \& Croteau, 1986).

The DM results were very similar to those of FM results (Table 2), although differences were found between these traits even when the leaves are dried up to constant weight. Santos \& Innecco (2003) studied the influence of the leaf drying period on the essential oil of Lippia alba and reported that the leaf moisture percentage tended to stabilize after the eighth day of natural drying, due to the hygroscopic balance that is established between the plant material and the environment. This balance is probably caused by the differences in leaf anatomy and morphology conditioned by the environment and the genetic structure among genotypes.

The virus symptoms assessment allowed the identification of a susceptible group, represented by the limonene/carvone genotypes (IAC-13 and IAC-14) (Table 3). The other genotypes were resistant to CMV, with general mean symptom severity values ranging from 1.1 to 1.7 , with genotypes IAC-2 and IAC-3 standing out as the most resistant.

The $G \times E$ interaction for VS was significant but no differences were found for the environment effect (experiments). The greatest variation in symptoms among the six experiments ranged from 1.0 to 2.2 for both IAC-9 and IAC-11, for which no virus symptoms were observed except rare mosaic in the leaves, with no statistical or agronomic significance. The fact of a significant $\mathrm{G} \times \mathrm{E}$ interaction was due to a low coefficient of variation $(12.1 \%)$ and changes in genotype ranking in the environments. Such changes invariably occurred in the group with rates below 2.2 (lack of, or a few symptoms), comprising genotypes IAC-1, IAC-2, IAC-3, IAC-4, IAC-9, IAC-10, IAC-11, and

Table 2 - Leaf dry matter means (two clones) for ten Lippia alba genotypes in six experiments, with genotype (G), environment (E) and $\mathrm{G} \times \mathrm{E}$ interaction effects detected by ANOVA and Tukey's test $(p<0.05)$.

\begin{tabular}{lccccccc}
\hline \multirow{2}{*}{ Genotypes* } & \multicolumn{7}{c}{ Environments* } \\
\cline { 2 - 6 } & $\mathrm{E} 1$ & $\mathrm{E} 2$ & $\mathrm{E} 3$ & $\mathrm{E} 4$ & $\mathrm{E} 5$ & E6 & \multicolumn{1}{c}{ Means } \\
\hline IAC-1 & $76.7 \mathrm{Ba}$ & $77.5 \mathrm{BCa}$ & $60.6 \mathrm{Ba}$ & $80.7 \mathrm{Ba}$ & $72.7 \mathrm{ABa}$ & $131.6 \mathrm{Aa}$ & $82.0 \mathrm{~B}$ \\
IAC-2 & $80.1 \mathrm{Ba}$ & $88.2 \mathrm{Bca}$ & $75.8 \mathrm{Ba}$ & $92.1 \mathrm{Ba}$ & $63.1 \mathrm{Ba}$ & $127.0 \mathrm{Aa}$ & $86.7 \mathrm{~B}$ \\
IAC-3 & $62.4 \mathrm{Ba}$ & $70.2 \mathrm{Bca}$ & $85.2 \mathrm{ABa}$ & $76.4 \mathrm{Ba}$ & $54.6 \mathrm{Ba}$ & $121.3 \mathrm{Aa}$ & $77.0 \mathrm{~B}$ \\
IAC-4 & $72.2 \mathrm{Ba}$ & $88.4 \mathrm{Bca}$ & $86.0 \mathrm{ABa}$ & $92.0 \mathrm{Ba}$ & $86.1 \mathrm{ABa}$ & $98.5 \mathrm{Aa}$ & $87.0 \mathrm{~B}$ \\
IAC-9 & $82.1 \mathrm{Bbc}$ & $33.2 \mathrm{Cc}$ & $91.6 \mathrm{ABb}$ & $57.3 \mathrm{Bbc}$ & $92.4 \mathrm{ABb}$ & $177.2 \mathrm{Aa}$ & $83.7 \mathrm{~B}$ \\
IAC-10 & $65.4 \mathrm{Bb}$ & $78.6 \mathrm{BCb}$ & $81.2 \mathrm{ABab}$ & $97.7 \mathrm{Bab}$ & $133.5 \mathrm{Aab}$ & $159.6 \mathrm{Aa}$ & $100.1 \mathrm{~B}$ \\
IAC-11 & $62.2 \mathrm{Bbc}$ & $44.2 \mathrm{BCc}$ & $86.8 \mathrm{ABbc}$ & $119.0 \mathrm{Bab}$ & $70.4 \mathrm{ABbc}$ & $202.3 \mathrm{Aa}$ & $91.5 \mathrm{~B}$ \\
IAC-13 & $91.1 \mathrm{ABb}$ & $107.4 \mathrm{Abab}$ & $85.7 \mathrm{ABb}$ & $107.5 \mathrm{Bab}$ & $95.3 \mathrm{ABb}$ & $184.4 \mathrm{Aa}$ & $109.8 \mathrm{~B}$ \\
IAC-14 & $47.2 \mathrm{Bb}$ & $91.4 \mathrm{BCb}$ & $77.0 \mathrm{Bb}$ & $61.7 \mathrm{Bb}$ & $61.1 \mathrm{Bb}$ & $185.9 \mathrm{Aa}$ & $82.6 \mathrm{~B}$ \\
IAC-16 & $160.9 \mathrm{Aabc}$ & $204.8 \mathrm{Aab}$ & $173.4 \mathrm{Aabc}$ & $265.2 \mathrm{Aa}$ & $106.0 \mathrm{ABc}$ & $131.1 \mathrm{Abc}$ & $169.8 \mathrm{~A}$ \\
\hline Means & $77.9 \mathrm{~b}$ & $83.7 \mathrm{~b}$ & $88.8 \mathrm{~b}$ & $99.6 \mathrm{~b}$ & $82.0 \mathrm{~b}$ & $150.1 \mathrm{a}$ & 95.6
\end{tabular}

$\mathrm{CV}=18.6 \% \mathrm{G} \times \mathrm{E}$ interaction*

Means followed by the same letter are not different $(p<0.05)$ between genotypes (capital letters) and environments (lower case letters). *Significant at $p<0.05$. E1: with both fertilization and irrigation (Campinas); E2: with fertilization but no irrigation (Campinas); E3: no fertilization but with irrigation (Campinas); E4: no fertilization or irrigation (Campinas); E5: Monte Alegre do Sul; E6: Pindorama. 
IAC-16, thus being considered resistant to the virus. The rating changes in the group that included the most susceptible genotypes (IAC-13 and IAC-14) had also very similar ratings (4.6 to 5.0) and did not change the ranking of any of the genotypes.

Two groups were formed in the oil yield evaluation: a productive group represented by the linalool (IAC-1, IAC-2, IAC-3, and IAC-4) and limonene/ carvone (IAC-13 and IAC-14) chemotypes (1.16 to $1.28 \%$ ) and a less productive group, represented by the myrcene/camphor (IAC-9, IAC-10, and IAC-11) and citral (IAC-16) chemotypes (0.27 to $0.37 \%)$ (Table 4).

The four Campinas experiments were not different among themselves for the OY evaluation, but were higher (0.90 to $0.93 \%)$ than E5 and E6 (0.76 and $0.74 \%$, respectively). E6 was the experiment that contributed towards $\mathrm{G} \times \mathrm{E}$ significance, mainly due to differences between genotypes in the most productive group. There was no variation in genotype behavior in the other five experiments.

Table 3 - Virus symptoms means (scale 1-5) for ten Lippia alba genotypes in six experiments, with genotype (G), environment (E) and $\mathrm{G} \times \mathrm{E}$ interaction effects detected by ANOVA and Tukey's test $(p<0.05)$.

\begin{tabular}{|c|c|c|c|c|c|c|c|}
\hline \multirow{2}{*}{ Genotypes* } & \multicolumn{6}{|c|}{ Environments* } & \multirow{2}{*}{ Means } \\
\hline & E1 & E2 & E3 & E4 & E5 & E6 & \\
\hline IAC-1 & $1.6 \mathrm{BCa}$ & $1.5 \mathrm{Ba}$ & $1.0 \mathrm{Ba}$ & $1.0 \mathrm{Ca}$ & $1.0 \mathrm{Ca}$ & $1.0 \mathrm{Ca}$ & $1.2 \mathrm{CD}$ \\
\hline IAC-2 & $1.0 \mathrm{Ca}$ & $1.2 \mathrm{Ba}$ & $1.2 \mathrm{Ba}$ & $1.3 \mathrm{BCa}$ & $1.0 \mathrm{Ca}$ & $1.0 \mathrm{Ca}$ & $1.1 \mathrm{D}$ \\
\hline IAC-3 & $1.0 \mathrm{Ca}$ & $1.3 \mathrm{Ba}$ & $1.0 \mathrm{Ba}$ & $1.0 \mathrm{Ca}$ & $1.1 \mathrm{BCa}$ & $1.0 \mathrm{Ca}$ & $1.1 \mathrm{D}$ \\
\hline IAC-4 & $1.3 \mathrm{BCa}$ & $1.4 \mathrm{Ba}$ & $1.5 \mathrm{Ba}$ & $1.4 \mathrm{BCa}$ & $1.1 \mathrm{Ca}$ & $1.0 \mathrm{Ca}$ & $1.3 \mathrm{CD}$ \\
\hline IAC -9 & $1.0 \mathrm{Ca}$ & $1.0 \mathrm{Ba}$ & $1.5 \mathrm{Ba}$ & $2.2 \mathrm{Ba}$ & $1.3 \mathrm{BCa}$ & $2.1 \mathrm{Ba}$ & $1.5 \mathrm{BC}$ \\
\hline IAC- 10 & $1.7 \mathrm{BCa}$ & $1.2 \mathrm{Ba}$ & $1.0 \mathrm{Ba}$ & $1.7 \mathrm{BCa}$ & $1.5 \mathrm{BCa}$ & $1.2 \mathrm{Ca}$ & 1.4 BCD \\
\hline IAC- 11 & $2.2 \mathrm{Ba}$ & $2.1 \mathrm{Ba}$ & $1.0 \mathrm{Ba}$ & $1.6 \mathrm{BCa}$ & $1.6 \mathrm{BCa}$ & $2.0 \mathrm{Ba}$ & $1.7 \mathrm{~B}$ \\
\hline IAC-13 & $5.0 \mathrm{Aa}$ & 4.7 Aa & $5.0 \mathrm{Aa}$ & $5.0 \mathrm{Aa}$ & $4.7 \mathrm{Aa}$ & 4.9 Aa & $4.9 \mathrm{~A}$ \\
\hline IAC- 14 & $4.6 \mathrm{Aa}$ & $5.0 \mathrm{Aa}$ & $5.0 \mathrm{Aa}$ & $5.0 \mathrm{Aa}$ & $5.0 \mathrm{Aa}$ & $5.0 \mathrm{Aa}$ & $4.9 \mathrm{~A}$ \\
\hline IAC- 16 & $1.3 \mathrm{BCa}$ & $1.0 \mathrm{Ba}$ & $1.0 \mathrm{Ba}$ & $1.0 \mathrm{Ca}$ & $1.7 \mathrm{Ba}$ & $1.1 \mathrm{Ca}$ & $1.2 \mathrm{CD}$ \\
\hline Means & $1.9 \mathrm{a}$ & $1.9 \mathrm{a}$ & $1.7 \mathrm{a}$ & $1.9 \mathrm{a}$ & $1.8 \mathrm{a}$ & $1.8 \mathrm{a}$ & 1.4 \\
\hline
\end{tabular}

$\mathrm{CV}=12.1 \% \quad \mathrm{G} \times \mathrm{E}$ interaction*

Means followed by the same letter are not different $(p<0.05)$ between genotypes (capital letters) and environments (lower case letters). *Significant at $p<0.05$. E1: with both fertilization and irrigation (Campinas); E2: with fertilization but no irrigation (Campinas); E3: no fertilization but with irrigation (Campinas); E4: no fertilization or irrigation (Campinas); E5: Monte Alegre do Sul; E6: Pindorama.

Table 4 - Oil yield means for ten Lippia alba genotypes in six experiments, with genotype (G), environment (E) and $\mathrm{G} \times \mathrm{E}$ interaction effects detected by ANOVA and Tukey's test $(p<0.05)$.

\begin{tabular}{|c|c|c|c|c|c|c|c|}
\hline \multirow{2}{*}{ Genotypes* } & \multicolumn{6}{|c|}{ Environments* } & \multirow{2}{*}{ Means } \\
\hline & E1 & E2 & E3 & E4 & E5 & E6 & \\
\hline IAC- 1 & $1.16 \mathrm{Abc}$ & $1.27 \mathrm{Aab}$ & $1.29 \mathrm{Aab}$ & $1.45 \mathrm{Aa}$ & $1.02 \mathrm{Abc}$ & $0.93 \mathrm{Bc}$ & $1.19 \mathrm{~A}$ \\
\hline IAC- 2 & $1.41 \mathrm{Aa}$ & $1.36 \mathrm{Aa}$ & $1.26 \mathrm{Aa}$ & $1.22 \mathrm{Aa}$ & $1.29 \mathrm{Aa}$ & $1.15 \mathrm{ABa}$ & $1.28 \mathrm{~A}$ \\
\hline IAC-3 & $1.27 \mathrm{Aab}$ & $1.26 \mathrm{Aab}$ & $1.28 \mathrm{Aab}$ & $1.44 \mathrm{Aa}$ & $1.07 \mathrm{Ab}$ & $1.02 \mathrm{ABb}$ & $1.22 \mathrm{~A}$ \\
\hline IAC- 4 & $1.38 \mathrm{Aa}$ & $1.30 \mathrm{Aa}$ & $1.13 \mathrm{Aab}$ & 1.26 Aab & $1.01 \mathrm{Ab}$ & $1.21 \mathrm{Aab}$ & $1.22 \mathrm{~A}$ \\
\hline IAC-9 & $0.41 \mathrm{Ba}$ & $0.41 \mathrm{Ba}$ & $0.40 \mathrm{Ba}$ & $0.42 \mathrm{Ba}$ & $0.26 \mathrm{Ba}$ & $0.32 \mathrm{Ca}$ & $0.37 \mathrm{~B}$ \\
\hline IAC- 10 & $0.36 \mathrm{Ba}$ & $0.37 \mathrm{Ba}$ & $0.43 \mathrm{Ba}$ & $0.36 \mathrm{Ba}$ & $0.31 \mathrm{Ba}$ & $0.37 \mathrm{Ca}$ & $0.37 \mathrm{~B}$ \\
\hline IAC- 11 & $0.37 \mathrm{Ba}$ & $0.33 \mathrm{Ba}$ & $0.37 \mathrm{Ba}$ & $0.35 \mathrm{Ba}$ & $0.31 \mathrm{Ba}$ & $0.27 \mathrm{Ca}$ & $0.33 \mathrm{~B}$ \\
\hline IAC- 13 & $1.21 \mathrm{Aa}$ & $1.19 \mathrm{Aa}$ & $1.30 \mathrm{Aa}$ & $1.24 \mathrm{Aa}$ & $1.07 \mathrm{Aa}$ & $1.03 \mathrm{ABa}$ & $1.17 \mathrm{~A}$ \\
\hline IAC- 14 & $1.13 \mathrm{Aab}$ & $1.23 \mathrm{Aa}$ & 1.27 Аa & $1.28 \mathrm{Aa}$ & $1.13 \mathrm{Aab}$ & $0.91 \mathrm{Bb}$ & $1.16 \mathrm{~A}$ \\
\hline IAC- 16 & $0.35 \mathrm{Ba}$ & $0.28 \mathrm{Ba}$ & $0.32 \mathrm{Ba}$ & $0.29 \mathrm{Ba}$ & $0.16 \mathrm{Ba}$ & $0.23 \mathrm{Ca}$ & $0.27 \mathrm{~B}$ \\
\hline Means & $0.90 \mathrm{a}$ & $0.90 \mathrm{a}$ & $0.91 \mathrm{a}$ & $0.93 \mathrm{a}$ & $0.76 \mathrm{~b}$ & $0.74 \mathrm{~b}$ & 0.86 \\
\hline
\end{tabular}

$\mathrm{CV}=15.7 \% \quad \mathrm{G} \times \mathrm{E}$ interaction*

Means followed by the same letter are not different $(p<0.05)$ between genotypes (capital letters) and environments (lower case letters). * Significant at $p<0.05$. E1: with both fertilization and irrigation (Campinas); E2: with fertilization but no irrigation (Campinas); E3: no fertilization but with irrigation (Campinas); E4: no fertilization or irrigation (Campinas); E5: Monte Alegre do Sul; E6: Pindorama. 
Still considering the most productive group, genotypes IAC-2 (linalool) and IAC-13 (limonene/ carvone) showed the most stable behavior for this trait in the experiments. On the other hand, IAC-1 (linalool) had the greatest oscillations, with similar results in $\mathrm{E} 2, \mathrm{E} 3$, and $\mathrm{E} 4$ (1.27 to $1.45 \%$ ) but different from E6 $(0.93 \%)$. In the group with yield lower than $0.5 \%$ (myrcene/camphor and citral chemotypes), no significant environmental variation was detected.

Environmental effects have been reported to cause alterations in OY according to harvest season (Santos \& Innecco, 2003; Innecco et al., 2003). These authors reported that yield increased considerably in the drought period, which was explained by temperature stress and increased light intensity. Oil yield variation was also observed in Mentha arvensis L. and Salvia officinalis L. during different seasons (Putievsky et al., 1986). For L. alba, Bahl et al. (2000) detected variations in this trait for different years. Therefore, the OY variations observed in this research could be considered low, bearing in mind that many factors were different in the various experiments: climates and soil conditions in E1 - E4, E5 and E6, fertilization and irrigation conditions in Campinas, in addition to the pres- ence of virus in some materials and different planting and harvesting dates in the six experiments.

Unlike previous observations for FM and DM of this study, the IAC-16 (citral) and IAC-10 (myrcene/ camphor) genotypes had the lowest oil yield mean. Because of the inverse relation observed between leaf production and essential oil production, it would be strategic in the genetic breeding of this species to transfer the leaf productive capacity (FM or DM) of the citral genotype to other chemotypes, or transfer higher OY to citral and myrcene/camphor individuals.

The genetic basis or heredity of these secondary metabolism substances has not been completely elucidated, which makes the actions of breeders more difficult. However, due to the broad phenotypic variation among the chemotypes observed for aerial traits, there could be significant genetic gains in a few generations of selection, initially concentrating in genetic breeding in order to increase leaf matter (FM or DM) and then oil yield.

As reported in material and methods, OC was assessed for each substance present above 5\% in the oil, individually, among genotypes that belonged to the same chemotype. Only quantitative substance variations

Table 5 - Means of chemical substance percentages in the oil, evaluated among Lippia alba genotypes of the same chemotype in six environments, with genotype $(\mathrm{G})$ and environment $(\mathrm{E})$ effects detected by ANOVA and Tukey's test $(p<0.05)$.

\begin{tabular}{|c|c|c|c|c|c|c|c|c|c|c|c|c|}
\hline \multicolumn{2}{|l|}{ Chemotype } & \multicolumn{2}{|c|}{ Linalool } & \multicolumn{4}{|c|}{ Myrcene/Camphor } & \multicolumn{2}{|c|}{ Limonene/Carvone } & \multicolumn{3}{|c|}{ Citral } \\
\hline Substance & $(\%)$ & linalool & 1,8-cineol & $\beta$-myrc & camphor & t-caryop & $\alpha$-fench & limonene & carvone & neral & geranial & $\beta$-myrc \\
\hline \multirow{6}{*}{ Environments } & E1 & $76.4 \mathrm{bc}$ & $11.0 \mathrm{ab}$ & $26.0 \mathrm{ab}$ & $30.5 \mathrm{ab}$ & $7.0 \mathrm{~b}$ & $6.9 \mathrm{ab}$ & $31.9 \mathrm{bc}$ & $50.0 \mathrm{~b}$ & $26.8 \mathrm{abc}$ & $36.3 \mathrm{a}$ & $16.0 \mathrm{abc}$ \\
\hline & E2 & $74.8 \mathrm{~cd}$ & $11.6 \mathrm{a}$ & $25.0 \mathrm{~b}$ & $28.1 \mathrm{ab}$ & $8.1 \mathrm{ab}$ & $6.6 \mathrm{~b}$ & $31.8 \mathrm{bc}$ & $50.3 \mathrm{~b}$ & $29.3 \mathrm{a}$ & 39.8 a & $14.3 \mathrm{c}$ \\
\hline & E3 & $75.3 \mathrm{~cd}$ & $11.1 \mathrm{ab}$ & $25.1 \mathrm{~b}$ & $31.8 \mathrm{a}$ & $6.9 \mathrm{~b}$ & $6.5 \mathrm{~b}$ & $29.7 \mathrm{c}$ & $52.8 \mathrm{a}$ & $28.3 \mathrm{ab}$ & 38.8 a & $14.8 \mathrm{c}$ \\
\hline & $\mathrm{E} 4$ & $74.5 \mathrm{~d}$ & $11.5 \mathrm{a}$ & $26.5 \mathrm{ab}$ & $30.2 \mathrm{ab}$ & $6.6 \mathrm{~b}$ & $7.0 \mathrm{ab}$ & $31.2 \mathrm{bc}$ & $50.7 \mathrm{~b}$ & $28.0 \mathrm{ab}$ & $38.8 \mathrm{a}$ & $15.0 \mathrm{bc}$ \\
\hline & E5 & $79.2 \mathrm{a}$ & $10.6 \mathrm{~b}$ & $26.6 \mathrm{ab}$ & $31.0 \mathrm{ab}$ & $7.5 \mathrm{~b}$ & $7.9 \mathrm{a}$ & $42.8 \mathrm{a}$ & $44.6 \mathrm{c}$ & $25.8 \mathrm{bc}$ & $37.5 \mathrm{a}$ & $19.3 \mathrm{a}$ \\
\hline & E6 & $78.0 \mathrm{ab}$ & $8.8 \mathrm{c}$ & $28.5 \mathrm{a}$ & $27.1 \mathrm{~b}$ & $10.2 \mathrm{a}$ & $6.6 \mathrm{a}$ & $34.6 \mathrm{~b}$ & $49.7 \mathrm{~b}$ & $24.3 \mathrm{c}$ & $35.3 \mathrm{a}$ & $18.5 \mathrm{a}$ \\
\hline \multirow{10}{*}{ Genotypes } & IAC- 1 & $75.7 \mathrm{a}$ & $11.2 \mathrm{a}$ & - & - & - & - & - & - & - & - & - \\
\hline & IAC-2 & $76.6 \mathrm{a}$ & $10.6 \mathrm{~b}$ & - & - & - & - & - & - & - & - & - \\
\hline & IAC - 3 & $76.9 \mathrm{a}$ & $10.7 \mathrm{ab}$ & - & - & - & - & - & - & - & - & - \\
\hline & IAC-4 & $76.3 \mathrm{a}$ & $10.6 \mathrm{~b}$ & - & - & - & - & - & - & - & - & - \\
\hline & IAC-9 & - & - & $26.6 \mathrm{a}$ & 29.8 a & $7.6 \mathrm{a}$ & $6.9 \mathrm{a}$ & - & - & - & - & - \\
\hline & IAC -10 & - & - & $25.9 \mathrm{a}$ & $30.1 \mathrm{a}$ & $7.8 \mathrm{a}$ & $6.9 \mathrm{a}$ & - & - & - & - & - \\
\hline & IAC- 11 & - & - & $26.4 \mathrm{a}$ & $29.5 \mathrm{a}$ & $7.8 \mathrm{a}$ & $7.0 \mathrm{a}$ & - & - & - & - & - \\
\hline & IAC -13 & - & - & - & - & - & - & $33.4 \mathrm{a}$ & $49.2 \mathrm{~b}$ & - & - & - \\
\hline & IAC- 14 & - & - & - & - & - & - & $34.2 \mathrm{a}$ & $50.2 \mathrm{a}$ & - & - & - \\
\hline & IAC- 16 & - & - & - & - & - & - & - & - & 27.0 & 37.7 & 16.3 \\
\hline General means & & 76.4 & 10.8 & 26.3 & 29.8 & 7.7 & 6.9 & 33.8 & 49.7 & 27.0 & 37.7 & 16.3 \\
\hline CV $(\%)$ & & 1.0 & 3.2 & 3.5 & 4.7 & 10.6 & 5.2 & 3.2 & 0.9 & 5.3 & 6.5 & 9.7 \\
\hline
\end{tabular}

Means followed by the same letter are not different $(p<0.05)$. E1: with both fertilization and irrigation (Campinas); E2: with fertilization but no irrigation (Campinas); E3: no fertilization but with irrigation (Campinas); E4: no fertilization or irrigation (Campinas); E5: Monte Alegre do Sul; E6: Pindorama; $\beta$-myrc: $\beta$-myrcene; t-caryop: trans-caryophyllene; $\alpha$-fench: $\alpha$-fenchene. 
were observed in the entire analysis, that is, no qualitative variation was detected, such as a new substance or the loss of others.

Both substances considered in the analysis of the linalool chemotype (linalool and 1.8-cineol) had significant environmental effects, but no genotype effect was observed for linalool (Table 5). While E5 and E6 were the experiments with the highest means of this compound, $79.2 \%$ and $78.0 \%$, respectively, they had the lowest values for 1.8 -cineol $(10.6 \%$ and $8.8 \%$, respectively).

The four substances assessed in the myrcene/ camphor chemotype ( $\beta$-myrcene, camphor, transcaryophyllene, and $\alpha$-fenchene) did not vary among genotypes. The magnitude of differences among environment means was lower than expected, considering the differences obtained for other traits, such as DM. These small differences indicated that the percentages of $\beta$-myrcene and trans-caryophyllene were inversely proportional to camphor and $\alpha$-fenchene. Variations in linalool and $\beta$-myrcene terpens were also reported in this species by Tavares et al. (2004); increased proportions of oil substances were obtained in vitro using plant growth regulators.

The environmental effect was significant for limonene and carvone. This was clearly observed from the inversion in the proportion of compounds for each individual experiment. The limonene production difference in E5 (42.8\%) to the second best experiment (E6) had a range greater than $8 \%$. Considering the experiment with the lowest limonene production (E3), this range reached $13 \%$. The same experiment, E3, was responsible for the greatest production of carvone (52.8\%), while E5 ranked last, with $44.6 \%$. The relative inversion of these two substances could be due to the fact that carvone is derived from limonene (Claus \& Edward, 1961). Santos \& Innecco (2003) also observed high variations in these two compounds, according to different leaf drying periods.

The citral chemotype was analyzed for only one genotype, IAC-16. Significant variations were detected for neral and $\beta$-myrcene. The experiments in Campinas had the highest neral means and the lowest $\beta$-myrcene means. The performance of plants for geranial was more stable and no environmental effect was detected for it.

The data suggest that the major oil components should be preferentially of genetic nature, with low interference of the environment in their alterations, as indicated by Tavares et al. (2005). Corrêa (1992) had already reported that although $L$. alba was subject to great morphological and phytochemical variations, the constituents of its essential oils did not vary. Nevertheless, such phenotypic plasticity in the proportion of substances (quantitative variation) may help understand the great diversity of environments where the species is found.

Although some differences observed in the OC analysis were found to be significant, they can be considered of low magnitude as a function of their low CV. This small variation was not expected since these genotypes differed for the other traits analyzed. However, it is strategic in genetic breeding to initially concentrate the selection process on indirect production traits, such as leaf production, oil yield, and disease resistance, and later focus on the relative proportion of substances in the oil.

Using a monosegmented method based on linear regression (Eberhart \& Russel, 1966), in the stability and adaptability evaluation for leaf dry matter, it was possible to verify the performance of genotypes in favorable and unfavorable environments, as well as their predictability (Figure 1). IAC-9 and IAC-16 had low stability, with $\mathrm{R}^{2}$ values equal to $52.7 \%$ and $2 \%$, respectively, and a significant regression deviation $\left(\sigma_{\mathrm{di}}^{2}\right)$. Moreover, IAC-9 had low adaptability in unfavorable environments $\left(\beta_{1}>1\right)$, while IAC-16 had low adaptability in favorable environments $\left(\beta_{1}<1\right)$. There were no significant regression deviations in the other genotypes; however, IAC-4 and IAC-10 also had low stability $\left(\mathrm{R}^{2}=59.2 \%\right.$ and $54.8 \%$, respectively), although the latter had broad adaptability $\left(\beta_{1}=1\right)$.

The ideal genotype must have high stability $\left(\mathrm{R}^{2}\right.$ $>60 \%$ and $\left.\sigma_{\mathrm{di}}^{2}=0\right)$ and broad adaptability $\left(\beta_{1}=1\right)$, in addition to a good mean (Cruz \& Regazzi, 1994). For instance, when $\beta_{1}>1$, the material is adapted or recommended only for favorable environments, since the slope is greater than $45^{\circ}$ and genotypes have very low productivity levels in unfavorable environments. IAC11 and IAC-14 fit this group, with $\beta_{1}=1.99$ and $\beta_{1}=$ 1.72 , respectively, even though they have a predictable behavior due to their stability parameters.

IAC-13, in the limonene/carvone chemotype, was the best genotype evaluated. It is a stable material with $\mathrm{R}^{2}=90.5 \%$ and a non-significant $\sigma_{\mathrm{di}}^{2}$ value (zero), and can be recommended for both favorable and unfavorable environments $\left(\beta_{1}=1\right)$. Therefore, its $\mathrm{DM}$ production of $109.8 \mathrm{~g}$ is the second best mean among the ten genotypes. Despite the fact that IAC-13 had reduced leaves as a sign of virus infection, the short internodes caused by dwarfism allowed the plant to have a good leaf production performance. Probably, its great adaptability can also be explained by the virus infection, which induces nonspecific plant defenses, indirectly ensuring less abiotic variations (genetic homeostasis). This hypothesis must be tested in plants with the same genetic composition (clones), with different levels of infection and healthy clones as controls. 


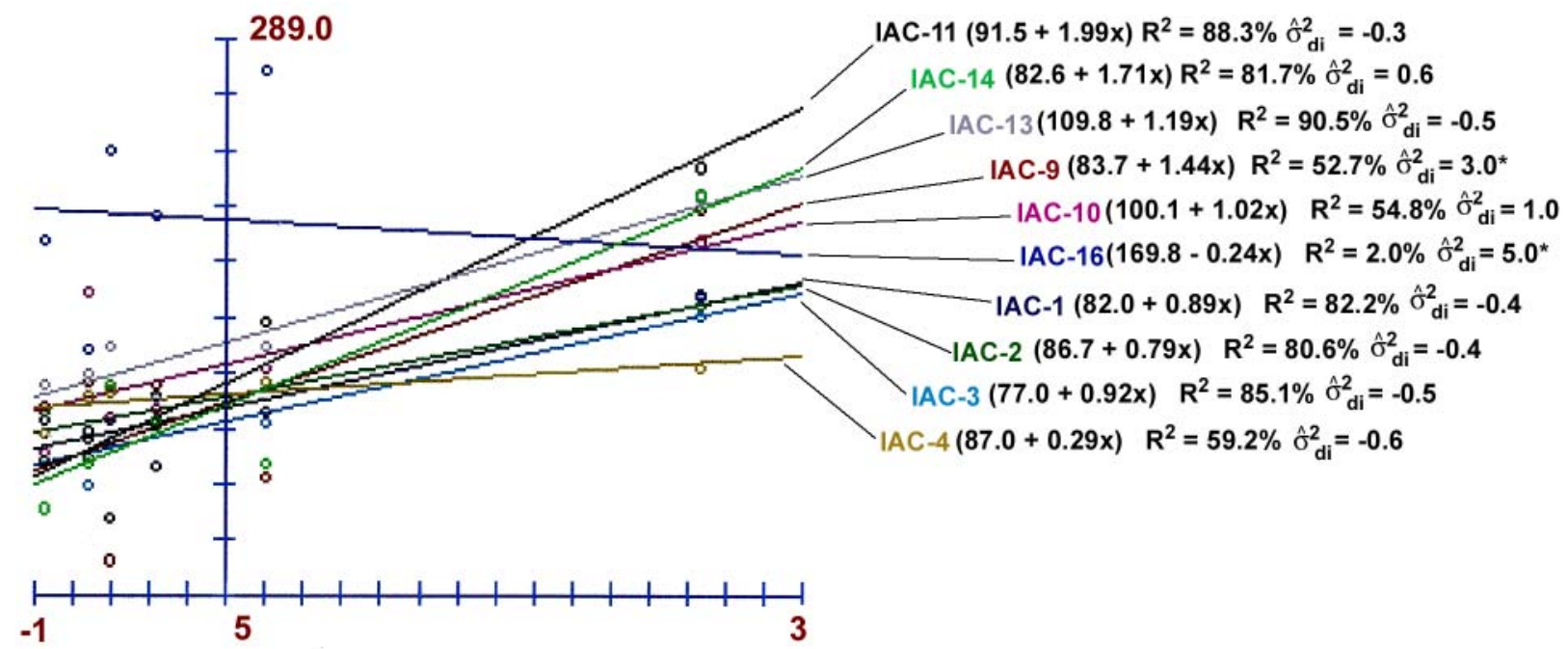

Figure 1 - Leaf dry matter stability and adaptability analysis for ten Lippia alba genotypes tested in six environments, represented by genotype means on the $\mathrm{Y}$ axis and adaptability indices $\left(\beta_{1}\right)$ on the $\mathrm{X}$ axis. The stability parameters of genotypic determination $\left(\mathrm{R}^{2}\right)$ and regression deviation estimates $\left(\hat{\sigma}_{d i}^{2}\right)$ are shown after each equation. *Significant $(p<0.05)$.

In relation to the linalool chemotype, the most commercial substance in this species, IAC-2 was classified as stable and responsive, and can be selected in the group because of its high production $(\mathrm{DM}=86.7 \mathrm{~g})$. The citral genotype, IAC-16, had a much superior mean for DM production (170 g) than any other genotype, as previously seen in the $\mathrm{F}$ test. On the other hand, this genotype is not predictable and not responsive to environmental improvements, thus being simply a rustic and productive material.

\section{CONCLUSIONS}

The $\mathrm{G} \times \mathrm{E}$ interaction has a wide range for leaf production, whereas oil yield had high and uniform genotypic determination. No qualitative variation was detected for oil chemical composition, and quantitative variations were of low magnitude. Linalool and limonene/carvone genotypes were invariably more productive for oil yield than citral and myrcene/camphor. Lippia alba genotypes IAC-2 (linalool) and IAC-13 (limonene/carvone) were the best materials to initiate a crop. Furthermore, IAC- 2 can be used in breeding programs as a source of virus resistance and oil productivity, while IAC16 can be a source of genes for increased leaf production.

\section{ACKNOWLEDGMENTS}

To CAPES and CNPq for awarding scholarships and Addolorata Colariccio (Instituto Biológico, São Paulo) for identifying the virus.

\section{REFERENCES}

ABAD, M.J.; BERMEJO, P.; VILLAR, A.; SANCHEZ-PALOMINO, S.; CARRASCO, L. Antiviral activity of medicinal plants extracts. Phytotherapy Research, v.11, p.198-202, 1997.

ADAMS, R.P. Identification of essential oil components by gas chromatography/mass spectroscopy. Carol Stream: Allured, 1995. 469p.

ALEA, J.A.P.; LUIS, A.G.O.; PÉREZ, A.R.; JORGE, M.R.; BALUJA, R. Composición y propriedades antibacterianas del aceite esencial de Lippia alba (Mill.) N. E. Brown. Revista Cubana de Farmácia, v.30, p.1-5, 1997.

BAHL, J.R.; GARG, S.N.; SINGH, S.C.; BANSAL, R.P.; NAQVI, A.A.; KUMAR, S. Composition of linalool from Lippia alba grown in Indian plains. Flavour and Fragrance Journal, v.15, p.199-200, 2000.

BHATNAGAR, J.K.; ASNARI, S.H. Effects of hormones on the growth and composition of Cymbopogon citratus and Cymbopogon jawarancusa. Indian Journal of Farmaceutical Science, v.44, p.15-19, 1988.

BRASILEIRO, B.G.; PIZZIOLO, V.R.; RASLAN, D.S.; JAMAL, C.M.; SILVEIRA, D. Antimicrobial and cytotoxic activities screening of some Brazilian medicinal plants used in Governador Valadares district. Revista Brasileira de Ciências Farmacêuticas, v.42, p.195-202, 2006.

CÁCERES, A.; ALVAREZ, A.V.; OVANDO, A.E.; SAMAYOA, B.E. Plants used in Guatemala for the treatment of respiratory diseases: screening of 68 plants against gram-positive bacteria. Journal of Ethnopharmacology, v.31, p.193-208, 1991.

CLAUS, P.H.; EDWARD, P. Pharmacognosy. Philadelphia: Lea \& Febiger, 1961. 565p.

CORRÊA, C.B.V. Contribuição ao estudo de Lippia alba (Mill.) N.E. Br. ex Britt \& Wilson - erva cidreira. Revista Brasileira de Farmácia, v.73, p.57-64, 1992.

CRUZ, C.D. Programa Genes: versão Windows. Viçosa: UFV, 2001. 642p.

CRUZ, C.D.; REGAZZI, J.A. Modelos biométricos aplicados ao melhoramento genético. Viçosa: UFV, 1994. 390p.

DOOL, H. van den; KRATZ, D.J. A generalization of the retention index system including linear temperature programmed gas-liquid partition chromatography. Journal of Chromatography A, v.11, p.463-471, 1963. 
DUBEY, N.K.; KISHORE, N.; SRIVASTAVA, O.P.; DIKSHIT, A.; SINGH, S.K. Fungitoxicity in some higher plants against Rhizoctonia solani. Plant and Soil, v.72, p.91-94, 1983.

DWIVEDI, S.K.; KISHORE, N. Fungitoxicity of some essential oils against Macrophomina phaseolina. Indian Perfumer, v.34, p.20-21, 1990.

EBERHART, S.A.; RUSSEL, W.A. Stability parameters for comparing varieties. Crop Science, v.6, p.36-40, 1966.

EL-KELTAWI, N.E.; CROTEAU, R. Influence of ethephon and daminozide on growth and essential oil content of peppermint and sage. Phytochemistry, v.25, p.1285-1288, 1986.

ELLABBAN, H.M. Effect of cycocel and spacings on the growth and volatile oil of Cymbopogon citratus. Scientia Horticulturae, v.8, p.237-242, 1978.

FRIGHETTO, N.; OLIVEIRA, J.G. Lippia alba Mill N.E.Br. (Verbenaceae) as a source of linalool. Journal of Essential Oil Research, v.10, p.578-580, 1998.

GOMES, E.C.; MING, L.C.; MOREIRA, E.A.; MIGUEL, O.G.; MIGUEL, M.D.; KERBER, V.A.; CONTI, A.; FILHO, A.W. Constituintes do óleo essencial de Lippia alba (Mill.) N. E. Br. (Verbenaceae). Revista Brasileira de Farmácia, v.74, p.2932, 1993.

IBRAHIM, M.A.; KAINULAINEN, P.; AFLATUNI, A.; TIILIKKALA, K.; HOLOPAINEN, J.K. Insecticidal, repellent, antimicrobial activity and phytotoxicity of essential oils: with special reference to limonene and its suitability for control of insect pests: review. Agricultural and Food Science in Finland, v.10, p.243-259, 2001

INNECCO, R.; CRUZ, G.F.; VIEIRA, A.V.; MATTOS, S.H.; CHAVES, F.C.M. Espaçamento, época e número de colheitas em hortelã-rasteira (Mentha $x$ villosa Huds). Revista Ciência Agronômica, v.34, p.247-251, 2003.

KISHORE, N.; MISHRA, A.K. Effect of essential oils on sclerential germination of Rhizoctonia solani. National Academy Science Letters, v.14, p.239-240, 1991.

MACHADO, A.A.; ZONTA, E.P. Manual do Sanest: Sistema de Análises Estatísticas para Microcomputadores. Pelotas: UFPel, 1991. 102p.

McLAFFERTY, F.W.; STAUFFER, D.B. The wiley/NBS registry of mass spectral data. New York: Hardback, 1989. 7872p.
MING, L.C. Influência da adubação orgânica na produção de biomassa e teor de óleos essenciais de Lippia alba. Horticultura Brasileira, v.12, p.49-52, 1994

PUTIEVSKY, E.; RAVID, U.; DUDAI, N. The influence of season and harvest frequency on essential oil and herbal yields from a pure clone of sage (Salvia officinalis) growth under cultivated conditions. Journal of Natural Products, v.49, p.326-329. 1986.

RAO, G.P.; SINGH, M.; SINGH, P.; SINGH, S.P.; CATALAN, C.; KAPOOR, L.P.S.; SINGH, O.P.; SINGH, G. Studies on chemical constituents and antifungal activity of leaf essential oil of Lippia alba (Mill.). Indian Journal of Chemical Technology, v.7, p.332-335, 2000.

SANTOS, M.R.A.; INNECCO, R. Influência de períodos de secagem de folhas no óleo essencial de erva-cidreira (quimiotipo limoneno/ carvona). Revista Ciência Agronômica, v.34, p.5-11, 2003.

SCHWAN-ESTRADA, K.R.F.; STANGARLIN, J.R.; CRUZ, M.E.R. Uso de extratos vegetais no controle de fungos fitopatogênicos. Floresta, v.30, p.129-137, 2000.

STEFANINI, M.B.; RODRIGUES, S.D.; MING, L.C. Ação de fitorreguladores no crescimento da erva-cidreira-brasileira. Horticultura Brasileira, v.20, p.18-23, 2002.

TAVARES, E.S.; JULIÃO, L.S.; LOPES, D.; BIZZO, H.R.; LAGE, C.L.S.; LEITÃO, S.G. Análise do óleo essencial de folhas de três quimiotipos de Lippia alba (Mill.) N.E.Br. (Verbenaceae) cultivados em condições semelhantes. Revista Brasileira de Farmacognosia, v.15, p.1-5, 2005.

TAVARES, E.S.; LOPES, D.; BIZZO, H.R.; LAGE, C.L.S.; LEITÃO, S.G. Kinetin enhanced linalool production by in vitro plantlets of Lippia alba. Journal of Essential Oil Research, v.16, p.405-408, 2004.

VAZ, A.P.A.; SCARANARI, C.; BATISTA, L.A.R.; FIGUEIRA, G.M.; SARTORATTO, A.; MAGALHÃES, P.M. Biomassa e composição química de genótipos melhorados de espécies medicinais cultivadas em quatro municípios paulistas. Pesquisa Agropecuária Brasileira, v.41, p.869-872, 2006.

Received May 04, 2007

Accepted April 04, 2008 